\title{
Türkiye Cumhuriyeti’nin Katıldığı İlk Uluslararası Organizasyon: 1924 Paris Olimpiyatları
}

\author{
Yrd. Doç. Dr. Nuray ÖZDEMIR*
}

\begin{abstract}
$\ddot{\text { Ozet }}$
Dünyanın en büyük uluslararası spor organizasyonu olan olimpiyatlara Türkiye Cumhuriyeti resmi olarak ilk defa 1924 yılında Paris'te katılmuştır. Kurtuluş Savaşl sonrasinda diplomatik yalnızlıktan kurtulma ve taninma mücadelesi veren yeni Türk Devleti olimpiyatları iyi bir propaganda aracı olarak görmüştür. Kıt kaynaklarına rağmen büyük bir özveri gösterip ödenek ayırarak; futbol, güreș, atletizm, eskrim ve bisiklet dallarında 40 sporcusunu Paris'e göndermiştir.

1924 Paris Olimpiyatları oldukça yoğun ve uzun süreli bir programla 4 Mayls 1924 'ten 27 Temmuz 1924 tarihine kadar yaklaşı üç ay sürmüş̧ür. 44 ülkeden 3089 sporcunun katıldı ̆̆ olimpiyatlarda Amerikall sporcular ön plana çıkarken Türk milli takımı kayda değer bir başarı elde edememiștir. Ancak Kurtuluş Savaşı'ndan yeni çıkmış Türkiye Cumhuriyeti'nin böyle büyük bir uluslararası organizasyonda ilk defa yer alması Türk halk için moral kaynağı olmuştur. Yeni Türk Devleti'nin dünyanın diğer ülkeleriyle yarışabileceği ve Türk bayrağını dünyaya tanıttı̆̆l düşüncesi başarısızllğı̆n önüne geçmiştir.

Bu çalışmada; Mustafa Kemal Paşa'nın liderliğinde kurulan Modern Türkiye Devleti'nin her alanda olduğu gibi spora verdiği önem dönemin basın ve arşiv belgelerine yansımaları doğrultusunda irdelenmiştir.
\end{abstract}

Anahtar Kelimeler: 1924, Paris, Olimpiyat, Türkiye, Spor.

\section{Abstract}

The First International Organization in Which The Turkish Republic Participated: 1924 Paris Olympics

Turkish Republic participated in the Olympics, the largest international sports organizations, officially for the first time in 1924 in Paris. The new Turkish State, struggling to be recognized and to escape from diplomatic isolation after the War of

\footnotetext{
* Abant İzzet Baysal Üniversitesi Fen Edebiyat Fakültesi Tarih Bölümü, Bolu
} 
Independence regarded the Olympics as a good method of propaganda. By showing substantial self-sacrifice and allocating funding in spite of its scanty resources, the country sent 40 sportsmen to Paris in football, wrestling, athletics, fencing and cycling.

The 1924 Paris Olympics lasted for about three months from May 4, 1924 to July, 27, 1924 with a rather intensive and lengthy program. While American sportsmen shone out in the Olympics in which 3089 sportsmen from 44 countries participated, the Turkish national team did not achieve any success. However, the fact that Turkish Republic, fresh from The War of Independence, participated officially for the first time in such an important international organization, created substantial moral support for the nation. The knowledge that the new Turkish State could compete with the other nations of the world and present the Turkish flag to the world outweighed the thought of being unsuccessful in the games.

This study investigates the importance given to sports, which like every area in the Modern Turkish State was founded under the leadership of Mustafa Kemal Paşa reflected in the media and archive documents of the period.

Key Words: 1924, Paris, Olimpics, Turkey, Sport.

\section{Giriş}

Eski Yunan'da M.Ö. 776'dan M.S. 393 yılına kadar her dört senede bir yapılmak üzere aralıksız düzenlenen barışın ve dostluğun sembolü olan oyunlar tarihte Antik (Eski) olimpiyatlar olarak anılmıştır. Yaklaşık 1500 yıl sonra olimpiyat oyunlarını yeniden canlandırma ve organize etme düşüncesi Fransa'da gelişmiştir. Fransız spor adamı Baron de Coubertin'in girişimi ile Haziran 1894'te Paris'te toplanan Uluslararas1 Spor Kongresi'nde olimpiyatların yeniden düzenlenmesi gündeme gelmiștir. Kongrenin ardından Uluslararası Olimpiyat Komitesi (IOC) kurulmuş ve 23 Temmuz 1894 tarihinde olimpiyatların yeniden düzenlenmesi kararlaştırılmıştır. Birinci olimpiyat oyunlarının 1896 yılında tarihi ilgisinden dolayı Atina şehrinde yapılması uygun görülmüştür.

Modern olimpiyatların başlangıcı Osmanlı Devleti’nin çöküş dönemine rastladığından Cumhuriyetin ilanına kadar olan süreçte Türk sporcularının olimpiyat oyunlarına katılımı ancak bireysel çabalarla mümkün olabilmiştir. Bunda ülkede yaşayan yabancılar ve gayrimüslimler tarafindan geliştirilen spor kavramının henüz yerleşmemiş olması kadar siyasi karışıklıklar ve savaşların sürdüğü ortam da etkili olmuştur. Osmanlı Devleti’ni

\footnotetext{
${ }^{1}$ Selim Sırrı, Beynelmilel Olimpiyat Oyunları, Türkiye İdman Cemiyetleri İttifakı Yayını, İstanbul, 1924, s.5-14.
} 
olimpiyatlarda gayri resmi de olsa ilk kez 1908 Londra Olimpiyatları'na özel davetli olarak katılan Galatasaray Lisesi öğrencilerinden Jimnastikçi Aleko Mulos temsil etmiştir. Olimpik örgütlenme ancak "hürriyetin ilanı" olarak anılan II. Meşrutiyetin 1908'de ilanından sonra söz konusu olmuştur. Baron de Coubertin ile temasta bulunan Selim Surrı (Tarcan) Bey'in öncülügünde Osmanlı Milli Olimpiyat Cemiyeti kurularak Türkiye'de olimpizmin temelleri atılmıştır. ${ }^{2}$ Uluslararası Olimpiyat Komitesi Stockholm'de 1912 yılında düzenlenecek V. Olimpiyat Oyunları'na Osmanlı Devleti'ni de davet etmiştir. Selim Sırrı Bey dönemin gazetelerine ilan vererek katılım için sporculara çağrıda bulunmuştur. Ancak devletin içinde bulunduğu ekonomik güçlükler nedeniyle hazineden olimpiyatlar için ödenek verilememesi ve sporcuların kendi harcamalarını kendilerinin karşılayacak olmasından dolayı beklenen ilgi olmamıştır. Sadece Vahram Papazyan ve Mıgırdiç Mıgıryan adlı Ermeni asıllı iki sporcu başvurmuş ve bu atletler kendi paralarıyla Osmanlı Milli Olimpiyat Cemiyeti ve Selim Sırrı Bey'in desteğiyle İsveç’te Osmanlı Devleti'ni temsil etmişlerdir. ${ }^{3}$

1916 yılında yapılacak altıncı olimpiyat için Berlin seçilmişse de I.Dünya Savaşı nedeniyle bu oyunlar yapılamamıştır. Savaş sonrasında 1920 yılında yeniden olimpiyatların düzenlenmesi gündeme gelmiş ve bunun için Belçika'nın Anvers şehri seçilmiştir. Olimpiyata Milletler Cemiyeti'ne dahil olmayan devletlerin çağrılmaması ilkesi benimsenmiştir. Türkiye savaşın sorumlusu olarak görülen Almanya, Avusturya, Macaristan ve Bulgaristan ile birlikte olimpiyatlara davet edilmemiştir. Zaten Balkan Savaşı, I.Dünya Savaşı ve Anadolu'da başlayan Kurtuluş Savaşı nedeniyle Osmanlı Milli Olimpiyat Cemiyeti dağılmıştır. Kurtuluş için mücadelenin yaşandığı böyle bir dönemde Türklerin olimpiyatlara çağrılmaması kamuoyunun gündeminde de yer almamıştır. Ancak olimpiyat için seçilen Anvers'in küçük bir şehir olması, yeterince hazırlık yapamaması ve dünyanın savaş yorgunluğundan hala kurtulamamış olmasından dolayı katılım az olmuştur. Hatta Türkiye gibi ülkelerde savaş devam ederken gerçekleşen 1920 Anvers Oyunları sönük geçmiştir. ${ }^{4}$ Dört y1l sonra yapılacak sekizinci olimpiyatlar için ise Paris seçilmiştir.

\footnotetext{
${ }^{2}$ Cem Atabeyoğlu, "Türkiye Milli Olimpiyat Komitesi”, Cumhuriyet Dönemi Türkiye Ansiklopedisi, C.8, İletişim Yayınları, (1983), s.2190., Olimpiyat Oyunlarının 100.Yılında Türkiye, (Der:Cüneyt E. Koryürek), Türkiye Milli Olimpiyat Komitesi Yayını, İstanbul, 1997, s.25-36.

${ }^{3}$ Haluk San, Belgeleri ile Türk Spor Tarihinde Olimpizm ve Olimpik Hareket, Hürriyet Ofset Matbaacılık ve Gazetecilik, İstanbul, 1985, s.23-24., Cem Atabeyoğlu, a.g.m., s. 2190.

${ }^{4}$ Atıf Kahraman, Osmanlı Devleti'nde Spor, Kültür Bakanlığı Yayınları, Ankara, 1995, s.711., Selim Sirr1, a.g.e., s.16.
} 


\section{Paris Olimpiyatları İçin Türkiye'ye Yapılan Davet}

Paris'te 1924 yılında yapılacak olimpiyatlarda da 1920 Anvers Oyunları'na katılım için benimsenen Milletler Cemiyeti üyesi olmayan devletlerin olimpiyatlara dahil edilmemesi koşulu geçerliliğini sürdürmüştür. Ancak cemiyete üye olmayan yeni Türk Devleti bu koşuldan muaf tutulmuştur. Türkiye'nin olimpiyatlara dahil edilmesini sağlamaya büyük önem veren ve savaş yılları boyunca Pierre de Coubertin ile temasını kesmeyen Selim Sırrı Bey'in çabaları sonuç vermiştir. ${ }^{5}$ Lozan'da Haziran 1921 'de toplanan Uluslararas1 Olimpiyat Komitesi'nde Türk, Bulgar ve Macar delegelerinin yeniden komiteye alınması görüşülmüştür. Pierre de Coubertin henüz barış anlaşması imzalanmamasına rağmen Türkiye'nin samimiyetine güvenildiğinden Türklerin uluslararası spor ailesine dahil edilmesinde 1srar etmiştir. Oldukça yoğun tartışmalardan sonra Belçika temsilcisi Baron de Laveleye, Çekoslavakya temsilcisi Jiri Guth-Jorkovsky ve Lüksemburg temsilcisi Maurice Pescatore'un reddetmesine karşın oy çokluğu ile kabul edilmiştir. ${ }^{6}$

Pierre de Coubertin Selim Sırrı Bey'e Türkiye'nin yeniden Uluslararası Olimpiyat Cemiyeti Türkiye temsilciliğine seçildiğini şu şekilde bildirmiştir: ${ }^{7}$

\section{Lousanne}

\section{Haziran 1921}

Aziz meslektaşım,

Beynelmilel olimpiyat cemiyeti son içtimaında Meclisimizde sizin yeniden Türkiye murahhasl olarak ahz-l mevki etmenize karar verdi ve bu karart size tebliğ için beni memur etti. Ahval sizi bir müddet bizden ayırmıştı. Hâlbuki hepimiz sizin şahsınıza karşın pek dostane bir hatıra beslemekte ber-devamdık. Hissiyat-ı hürmetkeranemin kabulünü rica ederim efendim.

\section{Beynelmilel Olimpiyat Cemiyeti Reisi}

\section{Baron Pierre de Coubertin}

Böylece Türk sporcularının olimpiyatlara katılması söz konusu olmuş ve Selim Sırrı Bey olimpiyatlar için yeniden örgütlenebilmek adına

\footnotetext{
${ }^{5}$ Selim Sirrı, a.g.e., s.17., Selim Sirrı, "1924 Olimpiyatlarl ve Lozan Mukarreratı", Spor Alemi, 8 Mart 1923, No:23, s.4.

${ }^{6}$ Kurthan Fişek, Türkiye Spor Tarihi, Gerçek Yayınevi, İstanbul, 1985, s.91., San, a.g.e., s.28.

${ }^{7}$ Spor Alemi, Temmuz 1922, No:10, s.3.
} 
çalışmalara hız vermiştir. Kurtuluş Savaşı'nın sürmesi ve İstanbul'un İtilaf Devletleri'nin işgali altında olması nedeniyle İstanbul'da örgütlenmede zorluklar yaşamıştır. Hasip (Bayındırlıŏlu) Bey’in başkanlığında Selim Sırrı Bey'in genel sekreterliğinde Şehzade Abdürrahim Efendi'nin fahri başkanlığ 1 ve Şehzade Ömer Faruk Efendi'nin koruyuculuğunda 25 Haziran 1922'de Milli Olimpiyat Cemiyeti yerine Cihan Müsabakalarına Hazırlanma Cemiyeti kurulmuşsa da Kurtuluş Savaşı'nın yoğun gündeminde bir etkinlik gösterememiştir. Aynı dönemde İstanbul'da Ali Sami (Yen) Bey başkanlığında ilk Türk spor örgütü olan Türkiye İdman Cemiyetleri İttifakı 31 Temmuz 1922'de kurulmuştur. Burhaneddin (Felek) Bey ikinci başkanlığa, Uluslararası Olimpiyat Komitesi Türkiye temsilcisi Selim Sırrı Bey de baş danışmanlığa seçilmiştir. ${ }^{8}$

Cihan Müsabakalarına Hazırlanma Cemiyeti kuruluşundan üç ay sonra Selim Sırrı Bey tarafından dağıtılarak 28 Ağustos 1922 tarihinde "Türkiye Milli Olimpiyat Cemiyeti" adıyla yeni bir oluşuma gidilmiştir. Cemiyet, Türkiye İdman Cemiyetleri İttifakı ile de işbirliği içinde faaliyet göstermeye başlamıştır. Sporda örgütlenme süreci devam ederken Paris Olimpiyat Oyunları Komitesi Başkanlığı 1924 Olimpiyatlarına Türk sporcularının katılımı için resmi davetini Uluslararası Olimpiyat Komitesi Türkiye temsilcisi Selim Sırrı Bey’e 20 Şubat 1923 tarihli şu mektupla yapmıştır: ${ }^{9}$

“20 Şubat 1923

Beynelmilel Olimpiyat Komitesi azasından Selim Sirrı Bey'e

Efendim

Beynelmilel Olimpiyat Cemiyeti sekizinci olimpiyatın Paris'te tes'idini (kutlama) taht-ı karara aldiğından 1924 oyunlarınin tertip ve tanzimine memur olan komite Paris'de icra edilecek müsabakalarla, şenliklere sizleri de davet etmek şerefiyle mübahidir (övünür). Mayls 3'den Mayls 19'a ragbi, Mayls 15'den Haziran 19'a futbol, Haziran 21'den 29'a endaht (aticillk) ve Temmuz 5'den 27'e olimpiyat programının ihtiva ettiği diğer müsabakalar icra edilecektir.

Ihtisasat-ı faikamın kabulünü rica ederim efendim.

Reis Kont Clary"

Resmi davetle birlikte Türklerin olimpiyata katılıp katılmayacağı ve katılacaksa hangi şubelere kaç kişi ile katılacakları da sorulmuştur. Türkiye

\footnotetext{
${ }^{8}$ San, a.g.e., s. 32 .

9 Selim Sirrı, "1924 Olimpiyatları ve Lozan Mukarreratı", Spor Alemi, 8 Mart 1923, No:23, s.5.
} 
Olimpiyat Komitesi temsilciliğine gelen bu mektup Türkiye İdman Cemiyetleri İttifakı'na iletilmiştir. Olimpiyatlara katılımla ilgili olumlu yönde cevap veren İdman Cemiyetleri İttifakı Türkiye'nin olimpiyatlara futbol, güreş, atletizm, binicilik ve nişancılık alanlarında katılabileceğini bildirmiştir. Selim Sırrı Bey bunun üzerine Uluslararası Olimpiyat Komitesi'ne Türkiye'nin olimpiyatlara katılacağ ${ }_{1}$ cevabını vermiştir. $^{10}$ Ancak böyle önemli bir organizasyona katılmak için çözülmesi gereken çok önemli meselelerle karşılaşılmıştır. Bunların başında savaştan tüm kaynaklarını tüketerek çıkan yeni Türk Devleti'nin olimpiyatları nasıl finanse edeceği gelmiştir. Özellikle günler geçip olimpiyatlar yaklaşmaya başlayınca öncelikle mali ve idari meselelerin çözümü önemli bir sorun olarak görülmüştür. Yaklaşık elli kişilik bir heyetle Paris'e gidip gelme, orada birkaç hafta kalma, sporcuların hazırlanması ve ihtiyaç duyulacak teçhizat masraflarına karşılık tahmini yirmi beş bin liraya ihtiyaç duyulmuştur. Ayrıca memur, asker, öğrenci olan sporcular için ilgili kurumlarından izin alınması, bütün bunlarda hükümetin desteğini sağlayabilmek ve gençleri hazırlamak için yurt dışından antrenör getirilmesi kısa zamanda yapılabilecek işler olarak görülmemiştir. ${ }^{11}$

\section{Sporda Örgütlenme ve Spor Çevrelerinin Hükümetle Olan İlişskileri}

Uluslararası Olimpiyat Komitesi Türkiye temsilcisi Selim Sırrı Bey, Türkiye'nin resmi spor örgütü olan Türkiye İdman Cemiyetleri İttifakı ile birlikte olimpiyatlara katılımla ilgili çalışmaları organize etmek için hemen harekete geçmiştir. Öncelikle Cumhuriyetin 29 Ekim 1923'te ilanından sonra Türkiye Milli Olimpiyat Cemiyeti yönetim kurulunu yeni konjonktüre göre düzenlemiştir. Yönetim kurulunda kendisi başkan, Hasib (Bayındırlıoğlu) Bey ikinci başkan, Türkiye İdman Cemiyetleri İttifakı Başkanı Ali Sami (Yen) Bey genel sekreter, Burhaneddin (Felek) Bey de üye olarak yer almıştır. $^{12}$ Daha önce Şehzade Abdürrahim Efendi’nin getirildiği fahri başkanlığa Başbakan İsmet Paşa seçilmiştir. İsmet Paşa'nın Türkiye Milli Olimpiyat Komitesi'nin bu kararını memnuniyetle karşılayarak kabul etmesi spor camiasında sevinçle karşılanmıştır. ${ }^{13}$ Böylece Cumhuriyetin ilanıyla spor dünyası da Ankara'yı ve Cumhuriyeti tek otorite kaynağı olarak tanıdığını göstermiştir.

\footnotetext{
${ }^{10}$ Burhaneddin, "1924 Olimpiyad Ne Olacak...", Spor Alemi, 22 Teşrin-i sani 1340, no:5, s.3., Selim Sirr1, a.g.e., s.19.

${ }^{11}$ Burhaneddin, a.g.m., s.3.

${ }^{12}$ San, a.g.e., s.39.

${ }^{13}$ BCA, 30..10.0.0/144.34..3./1483.
} 
Türkiye Milli Olimpiyat Cemiyeti ilk toplantısını 2 Kasım 1923 Pazar günü yapmıştır. Ne Cemiyetin ne de İdman Cemiyetleri İttifakı'nın mali durumlarının olimpiyatları finanse edecek durumda olmaması nedeniyle Paris'te yapılacak VIII. Olimpiyat Oyunları'na katılabilmek için hükümetten yardım istenmesi oy birliği ile kararlaştırılmıştır. Milli Olimpiyat Cemiyeti ve Türkiye İdman Cemiyetleri İttifakı birlikte hareket ederek Maarif Vekâleti'ne başvuruda bulunmuşlardır. Türkiye Cumhuriyeti yeni kurulduğundan ve savaşlardan harap olmuş ülkede yapılacak öncelikli pek çok işin olduğu bir ortamda başta başvuruyu yapan Selim Sırrı Bey ve Ali Sami Bey, para sıkıntısı yaşayan hükümetin bu yardım talebine sıcak bakacağından pek de umutlu olmamıştır. ${ }^{14}$

Gençlere büyük spor heyecanları yaşatabilmek düşüncesiyle olimpiyata katılma kararı yeni Türk Devleti'nin propagandasını yapma firsatı olarak görüldüğünden siyasal çevrelerce desteklenmiştir. Kurtuluş Savaşı sonrasında yaşanan diplomatik yalnızlıktan kurtulma ve tanınma mücadelesi veren Türkiye Cumhuriyeti Hükümeti olimpiyatları iyi bir firsat olarak görmüştür. ${ }^{15}$ Olimpiyatlar kültürel bir mesele olarak değerlendirdiğinden Maarif Vekâleti bu konu ile meşgul olmuştur. Maarif Vekili Sefa Bey 14 Kasım 1923 tarihli telgrafinda hükümetin yardımda bulunmayı kabul ettiğini ve gençlerin 1924 olimpiyatlarına katılabilmesi için ne gibi yardıma ihtiyacı duyulduğunun bildirilmesini istemiştir. Böylece hükümet ile spor çevreleri arasında ilk resmi temas yaşanmıştır. ${ }^{16}$

Maarif Vekâleti'nin isteği üzerine Türkiye İdman Cemiyetleri İttifak1 belgelerle desteklenmiş bir dosya hazırlayarak olimpiyatların Türk gençlerinin bedeni, fikri ve ruhi gelişimi için önemini belirtip ihtiyaçlarını bildirmiştir. Mali ihtiyacın 27 bin lira olduğu ve bunun 6.600 lirasının üç yabancı antrenörün getirilmesine harcanacağı ayrıntıları ile gösterilmiştir. ${ }^{17}$ Bu talebin hemen sonrasında Maarif Vekaleti İdman Cemiyetleri İttifakı'na bir telgraf göndererek Ankara'ya bu konu ilgili uzman gönderilmesini istemiştir. İttifak bu telgrafa teşekkür etmiş ve Başkan Ali Sami Bey'in Ankara'ya giderek hükümetle temasa geçeceği bildirilmiştir. Maarif Vekili bu konuda Vakit ve Vatan gazetelerine verdiği beyanatta da sporculara elden

\footnotetext{
${ }^{14}$ Cem Atabeyoğlu, Sporda Devlet mi? Devlette Spor mu?, Türkiye Milli Olimpiyat Komitesi Yayınları, İstanbul, 2001, s.9-10., Haluk San, Türk Sporunda Atatürk, Toplumsal Dönüşüm Yayınları, İstanbul 2000, s.92.

${ }^{15}$ San, a.g.e., s.39., Fişek, a.g.e., s.109.

16 Burhaneddin, "Hükümetin Spora Karşı Şayan-ı Şükran Alakası", Spor Alemi, 13 Kanun-1 sani 1924, No:8-9, s.3.

${ }^{17}$ San, a.g.e., s.41.
} 
geldiğince her türlü yardımın yapılacağını ve talep edilen paranın verileceğini, cumhuriyet gençliğinin buna layık olduğunu belirtmiştir. ${ }^{18}$

Türk sporunun gelişimi için yapılması gerekenler hakkında bilgi vermek üzere temsilci olarak İstanbul'dan Ankara'ya giden Ali Sami Bey Maarif Vekâleti Vekili Necati Bey ile birlikte Başvekil ve Hariciye Nazırı İsmet Paşa tarafından kabul edilmiştir. Türk sporunun gelişimi için hükümetin sporcuları himaye ederek kendilerine gereken yardımın yapılmasını istemiştir. İsmet Paşa Türk gençliği için sporun pek çok faydası olacağını gerek ordunun gerekse bütün gençlerin spor sayesinde iyi bir sağlığa sahip olarak vatana hizmette bulunacaklarını ve sporun gençleri iyi ahlaklı olmaya yönelteceğini belirterek Ali Sami Bey'den Türk sporcularının bu konudaki talep ve arzularını sormuştur. Ali Sami Bey, Paris'te yapılacak olimpiyatlara Türk sporcularına yakışır şekilde katılımın temin edilmesi ile atıcılık ve binicilik dallarında temsilin ordu tarafindan yapılmasının sağlanmasını istemiştir. ${ }^{19}$ Olimpiyatların finansmanı için de hükümetten 17.000 lirası acil olmak üzere 27.000 lira talep etmiştir. ${ }^{20}$

\section{Olimpiyatlar İçin Hükümetin Para Yardımı}

Demiryolu yapımı ve mübadele işleri gibi çok önemli işlerle meşgul olunmasına rağmen 1924 olimpiyatlarına katılma ve sporun ülkenin her tarafinda gelişmesini sağlamada başta Mustafa Kemal Paşa, İsmet Paşa, Maarif Vekili ve diğer hükümet üyeleri desteklerini esirgememişlerdir. İlk olarak Türkiye İdman Cemiyetleri İttifakı'nın kamu yararına çalışan bir dernek olduğu 16 Ocak 1924 tarihli ve 170 sayılı Bakanlar Kurulu Kararı ile kabul edilmiştir. ${ }^{21}$ Aynı gün Bakanlar Kurulu olimpiyatlar için kullanılacak 17.000 liranın bu cemiyete verilmesini kararlaştırmıştır. 16 Ocak 1924 tarihli 171 sayılı Bakanlar Kurulu kararı şu şekildedir: ${ }^{22}$

"Türk gençleri arasindaki spor müesseselerinin Avrupa sporcularıla sikı bir temasta bulunmalar ve spor faaliyatının fenni esasata terfiken tanzim hususunda Avrupa mütehassislartndan istifade edilmesi zaruridir. 1924 Mayısında Paris'te küşadı mukarrer olimpiyat müsabakalarına Türkiye İdman Cemiyetleri ittifakı da davet olunmuştur. Bu müsabakaya iştirak etmekte Türkiye için menafi vardır. Ve memleketimizde sporculuğun terakki ve teammüm (gelişip yayılmast) etmesi her halde bu gibi beynelmilel

\footnotetext{
${ }^{18}$ Burhaneddin, a.g.m., s.4.

${ }^{19}$ Spor Alemi, 13 Kanun-1 sani 1924, No:8-9, s.45.

20 Akşam, 23 Kanun-1 sani 1924, s.2., Yusuf Ziya, "Olimpiyat Oyunlarına Nasıl Gidiyoruz?", Vakit, 29 Şubat 1924, s.3.,Vakit, 23 Kanun-1 sani 1924, s.3.

${ }^{21}$ BCA, 30..18.1.1/8.47..14/-.

${ }^{22} \mathrm{BCA}, 30 . .18 .1 .1 / 8.46 . .5 / 148-1$.
} 
müsabakalara iştirakle mütevaffiktır (katılmaya yöneliktir). Binaenaleyh Türk gençlerini beynelmilel müsabakalara iştirak ettirebilecek surette talim ve ihzar etmek üzere icab eden Mütehassisların Avrupa'dan celbi ve mezkur olimpiyad müsabakalarına Türk idmancılarının da iştirakı esbabının temini için müstahcilen sarfi lüzum görülen on yedi bin liranın musarıf-ı gayri melhuze tertibinden Türkiye İdman Cemiyetleri Ittifakl merkez-i umumiyyesine verilmesi takarrrür etmiştir."

Bu paranın 6.000 lirasının futbolcu, güreşçi ve atletleri yetiştirmek için yurt dışından getirilecek üç antrenöre verilmesi, 2.000 lirasının bilimsel içerikli spor eserlerinin basılmasına ayrılması, 4.000 lirasının eğitim için gereken araç gerecin alınmasına harcanması geri kalan 5.000 liranın ise olimpiyata katılmak üzere gidecek sporcuların yiyecek ve barınma gibi Paris’teki masraflarını karşılamak üzere tahsis edilmesi öngörülmüştür. ${ }^{23}$ İdman Cemiyetleri İttifakı bu parayı 10 Şubat 1924 tarihinde alarak ihtiyaçlar için kullanmaya başlamıştır. ${ }^{24}$

Uluslararası Olimpiyat Komitesi'nin Türkiye temsilcisi ve Milli Olimpiyat Komitesi Başkanı Selim Sırrı Bey, hükümetin olimpiyat işlerine verdiği önem karşısında Başbakan İsmet Paşa'ya 2 Şubat 1924 tarihli bir teşekkür yazısı göndermiştir. Türkiye'nin olimpiyatlara katılmasının önemini vurgularken son derece gerçekçi bir şekilde elde edilecek sonucun birincilik düzeyinde olamayacağını da şu şekilde ifade etmiştir: ${ }^{25}$

"Fransizlar tarafindan 1896' da yeniden ihya ve her dört senede bir muhtelif payitahtlarda icra olunan beynelmilel olimpiyat müsabakalarına iştirak eden kırk dört millet içinde varlığını gösterememek bilhassa vaktiyle kuvvetiyle şöhret alan bir millet için bir az ayıp oluyordu. Hepsi bir tarafa birkaç yüz bin kişi huzurunda yapılan muazzam bir ihtifalde (törende) Yunan bayrağının arkasında elli kadar palikarya (Yunancada delikanlı) bulunduğu halde bizimkinin arkasında kimse bulunmaylşı intizar-l alemde bizi küçük düşürüyordu. Güreşci, atlayıcı, koşucu, futbolcu olmak üzere bu meşher-i ebdanı (bedenlerin teşhir yerine) himmetinizle götüreceğiz Otuz kadar gencin Amerika, İngiltere, İsveç, Finlandiya gibi sporu şiar-ı milli ( milli ilke) mahiyetine getiren memleketlerin efradının elinden birincilik almak ne bu sene ne de dört sene sonra- Lahey'de 1928 Olimpiyatları'nda-adim'i-l imkandır (imkansizdir). Ancak Romanya, Bulgaristan, Yunan, İspanya, Portekizlilerle hem ayar olduğumuzu göstermek mümkün olabilecektir.

\footnotetext{
${ }^{23}$ Vakit, 23 Kanun-1 sani 1924, s.3.

${ }^{24}$ Vakit, 3 Mayis 1924, s.4.

${ }^{25}$ BCA, 30..10.0.0/144.34..12/14812.
} 
Herhalde gençlik teveccühünüzü kesb-i istihkak (hak kazanmak) etmekle ve milletin yüzünü kara çıkarmamaya gayret edecektir."

Bakanlar Kurulu'nun 1924 Paris Olimpiyat Oyunları için kıt kaynaklarına rağmen sporu desteklemesi dolayısıyla Türkiye İdman Cemiyetleri İttifakı Başkanı ve Türkiye Milli Olimpiyat Komitesi Genel Sekreteri Ali Sami Bey de cumhurbaşkanlığına bir teşekkür telgrafi göndermiştir. Bu telgrafa Cumhurbaşkanı Mustafa Kemal Paşa 24 Mart 1924 tarihli şu karşılığ 1 vermiştir: ${ }^{26}$

“İstanbul, Türkiye İdman Cemiyetleri Reisi Ali Sami Bey’e

Hissiyatınıza teşekkür ederim. İdmancılarımızın pek müfit ve atimiz için ümitbahş mesaisinde daima nail-i müzaheret olacaklarına itimat ediniz.

24 Mart 1924

Türkiye Reis-i Cumhuru Gazi Mustafa Kemal"

Ayrıca uluslararası müsabakalara katılma ve sporun teşviki için spor teşkilatlarına verilmek üzere bütçeden y1llık 50.000 liralık bir ödenek ayrılması da benimsenmiştir. ${ }^{27}$ Milletvekillerinin çoğunlukla spora taraftar olması ve askerlik hizmeti söz konusu olduğunda sporun buna olan etkisi herkesçe bilindiğinden bir itiraz olmadan 5.220.000 lira olan 1924 y1l bütçesinden 50.000 liranın tahsisi TBMM'nin 17 Nisan 1924 tarihli toplantısında kabul edilmiştir. ${ }^{28}$ Böylece yeni kurulan Türkiye Cumhuriyeti Devleti sporcuya, sporun gelişmesi ve yaygınlaşmasına verdiği önemi bu kanunla ortaya koymuştur. Ekonomik güçlüklerle boğuşan devletin imkânlarını zorlayarak ülkede sporun gelişmesi için kaynak aktarması dönemin yöneticilerinin spora verdiği önemin bir sonucu olarak kendini göstermiştir.

Hükümetin olimpiyatlara katılımı desteklemesiyle birlikte bir taraftan sporcuların eğitimi için antrenör bulma meselesi diğer taraftan da ordu içinden seçilecek sporcuların tespitine önem verilmiştir. Binicilik ve atıcılık sporcularının ordu içinden seçilip hazırlanması öngörülmüştür. İsmet Paşa bu konuya da eğilerek yaveri süvari binbaşısı Atıf Bey'den binicilik konusunu araştırmasını istemiştir. Atıf Bey mevcut atlarla yarışlara katılmanın mümkün olamayacağını, bu yarışlara girmek için İrlanda'dan on

\footnotetext{
${ }^{26}$ San, a.g.e., s.44.

${ }^{27}$ BCA, 30..30.0.0/ 144.34.12/ 14812., TBMM Zabıt Ceridesi, Devre:II, Cilt:7, İçtima Senesi:II, On ikinci İçtima, 15.3.1340, s.37.

${ }^{28}$ Akşam, 23 Kanun-1 sani 1924, s.2., TBMM Zabıt Ceridesi, Devre:II, Cilt:8/1, İçtima Senesi:II, Kırkıncı İçtima, 17.4.1340, s.835.
} 
hayvan getirilmesi gerektiğini bildirmiştir. Bu öneri zaman alacağ ertelenmiştir. Atıcılık konusunda da bu işi Endaht Mektebi'nin yapması düşünülmüş ancak okul henüz eğitime başlamadığından bu konuda kesin bir karar hemen alınamamıştır. Atıcılık yarışlarına Türkiye'nin katılması mümkün olabileceğinden hükümet bu konunun takibini bırakmamıștır. Bunlar için İstanbul'a antrenörler getirilmesi ve olimpiyat yönetmeliğinin tercüme edilip basılması işlerine öncelik verilmiştir. ${ }^{29}$

\section{Olimpiyatlara Katılımın Gerekli Olup Olmadığına Dair Tartışmalar}

Hükümetin olimpiyatlar için verdiği destek yoğun eleştirileri de beraberinde getirmiştir. $\mathrm{O}$ zamana kadar olimpiyatlara ilgi göstermemiş, hatta bu konuda hiç haber yapmamış birçok gazetede "Paris'e gidelim mi, gitmeyelim mi?" konusu tartışılmıştır. Gazetelerde, Türk gençliğinin olimpiyatlara katılacak dereceye ulaşmadığ 1 iddia edilerek mahcup olunacağ 1 ve "Paris'e gitmek beyhudedir, bu seyahat bazı kimselerin Paris'i görmeleri için yapılıyor" yönünde eleştiriler yer almıştır. ${ }^{30}$

Bu tartışmaları başlatan 6 Şubat 1924 tarihinde Akşam Gazetesi'nde Ali Naci imzalı "Olimpiyata Behemehâl Gitmeli miyiz, Gitmesek $\mathrm{Ne}$ Kaybederiz?" başlıklı yazı olmuştur. Hükümetin olimpiyata katılmak için verdiği para yardımının önemi vurgulanırken devletin fakir olmasına rağmen en önemli ihtiyaçlarından kesip kırparak spora ayırdığı paranın İdman Cemiyetleri İttifakı'nca en iyi şekilde ihtiyaç duyulan şeylere harcanması tavsiye edilmiştir. Hatta bu para alınırken hükümetin spor çevrelerince yanlış bilgilendirilerek kandırıldığ $\breve{g}$ dile getirilmiştir. Bir spor adamı olarak Ali Sami Bey'in çeşitli vesilelerle daha önce olimpiyatlarda derece elde etmek mümkün olmadığını belirtmesine rağmen şimdi mutlaka olimpiyata gitmek, orada bir şeref kazanmak için değil, fakat her müsabakada sonuncu çıkıp fena bir tesir bırakmak pahasına da olsa gitmeyi istediğini ve hükümeti de bu yönde bilgilendirmediğine dair şunlar yazılmıştır: ${ }^{31}$

"Hiçbir hükümet hiçbir rical-i devlet spor işlerinde mütehassis olmak mecburiyetinde değildir. Hükümetin vazifesi ve maksadı sporun inkişafina masruf faaliyetin her vechle takviye etmek, spor için çalışanlarl, spor mütehassisların kendi selamet ve kudretinden istifade ettirmek, onların ihtiyaçların tehvin eylemek, manen yardım etmek, maddeten para vermektir. İsmet Paşa hükümeti de maksadına vasıl olmak için, vazifesini pekiyi idrak

\footnotetext{
${ }^{29}$ Vakit, 23 Kanun-1 sani 1924, s.3.

${ }^{30}$ Yusuf Ziya, "Olimpiyat Oyunlarına Nasıl Gidiyoruz?”, Vakit, 29 Şubat 1924, s.3

${ }^{31}$ Ali Naci, "Olimpiyata Behemehal Gitmeli miyiz, Gitmesek Ne Kaybederiz?", Akşam, 6 Şubat 1924, s.3.
} 
eden bir zihniyetle Türkiye İdman Cemiyetleri İttifakl'na karşı bu hatt-ı hareketi takip etmiştir. Taleplerini iyi niyetle dinlemiş dikkate almış, yardım vaat etmiş, para vermiştir. Fakat zan ediyoruz ki, hükümet, "gidecek halde olmasak bile behemehâl olimpiyata gidiniz, gitmeniz için de size 27.000 lira veriyorum!" demiş olsun. Buna ihtimal vermeyiz. Anlaşılması lazım gelen nokta İdman Cemiyetleri Itttifakı murahhasının Ankara'da temas ettiği zevata bizim olimpiyata iştirak edemeyecek bir halde olduğumuzu söyleyip söylemediği noktasıdır. Mademki kendisi tenvir (aydınlatma) maksadıyla davet edildi bunu söylemeli idi..."

Pek çok milletin olimpiyatlar için çok iyi hazırlanmasına karşın savaşlardan yeni çıkmış Türk sporcularının olimpiyat için hazır olmadığ 1 eleştirilerin esas noktasını oluşturmuştur. Ali Naci, “... bir tek mütehassis var mıdır ki karşımıza çıksın da evet biz olimpiyatlarda Türk bayrağını şerefle dalgalandirabilecek bir haldeyiz behemehal gitmeliyiz diyebilsin. Bunu soruyoruz?" diyerek sporcuların olimpiyatlara hazır olmadığını eğer bir sene önce olimpiyata gidebilmek için hazırlıklara başlanıp Avrupa'dan antrenörler getirilip muntazaman çalıştırılsalardı olimpiyatlara katılımın söz konusu olabileceğini savunmuştur. Ülkede jimnastikhane, spor sahası, güreş salonu hatta bir güneş minderi bile olmadığını, bu kadar yokluk içinde iken olimpiyatlara katılmanın imkansızlığını göstermeye çalışırken olimpiyatların propaganda arac1 olarak kullanabileceği düşüncesine ise şöyle karşı çıkmıştır: "Olimpiyata iştirak edecek halde değiliz ancak propaganda için gideceğiz fikri de doğru değildir. Propaganda için, ancak bu tezahür edeceğimiz kuvvetin bir tesir yapabileceğini bizce muhakkak olduğu zaman gidelim. Yoksa yapılacak lehimize değil aleyhimizedir... Avrupa'da zaferlerimiz dolaylsiyla çok kuvvetli bir millet olarak telakki ediliyoruz. Fenne ve ilme istinad eden sporun muhtelif şubelerinde hazırlanmamıs olmak yüzünden zaafimı tezahür ederse bu adamlar hakkında fikrimiz yanlışmış hiç de kuvvetli değiller demezler mi?" Bu nedenle olimpiyatlara katılımın ülke için bir fayda sağlamayacağı aksine 27.000 liranın yol ve otel parası olarak heba edileceğine bu paranın İstanbul'da ya da Türkiye'nin her hangi bir bölgesinde kullanılabileceğini savunmuştur. Bu para ile birkaç spor salonunun açılması daha fazla yarar sağlanacağından 27.000 liranın parasızlık nedeniyle iş göremeyen spor kulüplerine verilmesi önerilmiştir. ${ }^{32}$

İkdam Gazetesinde "Paris Tenzihinin İç Yüzü Yanlış" başlıklı imzasız yer alan bir yazıda ise Uluslararası Milli Olimpiyat Komitesi Türkiye

\footnotetext{
32 Ali Naci, "Olimpiyata Behemehal Gitmeli miyiz, Gitmesek Ne Kaybederiz?”, Akşam, 6 Şubat 1924, s.3.
} 
temsilcisi Selim Sırrı Bey şu şekilde eleştirilmiștir: ${ }^{33}$ "Selim Sirrı bey Paris'e gitmek için musarıf olarak 30.000 küsur lira almıştır. Selim Sırrı Bey'in musarlf listesini görenler hayretler içinde kalmışlardır. Smokin takımından vereceği ziyafetlere kadar hesap etmiştir. Hatta bu parayı koparabilmek için bir zamanlar İstanbul'da birtakım dolaplar çeviren Mösyö La Kruva ${ }^{34}$ ismindeki bir Fransızın mektuplarını işhad etmiştir. Bu mektuplarda güya Paris'te Türk futbolcuları için mükemmel bir şato ihzar edildiği ve iaşe masrafinın da düşünülmekte olduğu bildiriliyormuş. Selim Sirrı Bey yola çıktıktan sonra şatonun asıl ve esası olmadiğ bildirilmiştir.” Bu eleştiriler karşısında Selim Sırrı Bey Cumhuriyet Gazetesi'nde 12 Mayıs 1924 tarihli "Paris Tenzihinin İç Yüzü Yanlış Hesap Bağdat'tan Döner" başlıklı makalesinde eleştirilerin haksızlığını şöyle göstermeye çalışmıştır:“...Yukarıdaki satırlardan benim adi bir düzenbaz, sahtekâr bir dolandırıcı olduğum anlaşıllyor. Sizden sorarım, otuz sene bila-fasıla memleketin gençliğine hayat ve sihhat vermek için uğraşmanın mükafatı bu mudur? ...Lütfen bana söyleyiniz Türkiye'yi temsil eden bir adam, Paris'te cihanın toplandĭ̆ bir mevsimde iki yüz elli lira ile iyice bir otelde yaşayabilir mi? Frak ve smokin ve ziyafet masrafinı listeye dahil etmek kabahat mi? Sirtıma elbise istemiyorum Reis-i cumhurun ziyafetinde ve geceleri gitmek zaruretinde bulunacağım merasimde bir iki defa giyeceğim elbiseyi de benim yaptırmaklığım iktiza eder mi idi! Ziyafete gelince siz Avrupa'da yaşadiniz, benden iyi bilirsiniz ki her memleketin mümessilleri ile beraber yaşanirsa yekdiğerine ziyafet vermek adettir. Bu ziyafetlere ya gitmemeli ya gidince mukabele etmeli... Şatoya gelince bize bir zengin adam parasız olarak ikametgahını bir müddet için vermeğe muvaffakiyet etmiş ve sonra bazı ahval hadis olmuş bu fikrinden caymış bunda benim ne taksiratım var. Şatoya mukabil bir rüşvet mi aldım?"

Türkiye İdman Cemiyetleri İttifakı içinde dahi olimpiyatlara gitme konusunda görüş birliği yoktur. Bu konuda Türkiye İdman Cemiyetleri İttifakı Boks Heyeti Başkanı Eşref Şefik Bey’in “1924 Olimpiyatına İştirakin Mahzurları" başlıklı Akşam Gazetesi'nde yayınlanan makalesi bu görüş ayrılığının en önemli göstergesi olmuştur. Eşref Şefik Bey'in görüşleri şu şekildedir:" "Altı ay evvel olimpiyat tahsisatının hükümetten alınamayacağını zan edenlerle gidilse bile muvaffakiyete yakın bir netice

${ }^{33}$ Selim Sırrı, "Paris Tenzihinin İ̧̧ Yüzü", Cumhuriyet, 12 Mayıs 1924, s.4.

${ }^{34} \mathrm{La}$ Kruva mütareke döneminde İstanbul'da bulunan Fransız ordusunda yüzbaşı olarak görev yapmıştır. Bu yıllardan itibaren bir Türk dostu olarak iki ülke arasında yakınlaşma sağlamaya çalışmıştır. Türkiye'nin olimpiyatlara katılması gündeme gelince Selim Sırrı Bey'e bir mektup göndererek Türk sporcularının Paris'te barınma ve ağırlanmasıyla ilgili bazı tekliflerde bulunmuştur. Bkz: BCA: 30..30.0.0/144.34..12/14812.

${ }^{35}$ Eşref Şefik, "1924 Olimpiyadına İștirakin Mahzurları", Akşam 12 Şubat 1924, s.3. 
elde edilemeyeceğine kani olanlar tahsisatın alındığı günün akşamında lisan ve kanaatlerini tebdil ederek teferruata aid tavsiyeler vermeye başladilar. Gün geçmiyor ki gazetelerde olimpiyata iştirak hayali birkaç satırla süslenmiş, hakikate bir az daha yaklaştırılmış olmasın..."

Gazetelerde yer alan olimpiyatlara katılmanın gereksizliğini iddia eden yazılara bir cevap olarak Vakit Gazetesi'nde Türkiye Atletizm Federasyonu Başkanı ve Güreş Federasyonu müfettişi Ali Seyfi Bey'in kaleme aldığ “Olimpiyata Niçin Gidiyoruz?” başlıklı bir makale oldukça dikkate değerdir. İlgili kuruluşlardan bilgi almadan yapılan yanlış haberleri eleştiren Ali Seyfi Bey, sporun medeni bir ihtiyaç olduğu üzerinde durmuş ve eleştirilere şu şekilde cevap vermiştir: ${ }^{36}$ "...olimpiyatların gayesini saniye ile metre ile ölçmek pek nakis (eksik) bir netice verir. Şüphesiz ki birinciler şerefli yedinciler şerefsiz diye bir kaide yoktur. Ölüp de tekrar dirilmiş bir milletiz, yaşamak hirsi bize bu hayati hamleyi yaptırdl. Bizi olimpiyata firlatacak olan işte o hamledir. Bizde bir şeyler var herhalde. Çünkü biz de bir milletiz."

Gazetelerde bu yoğun tartışmalar sürerken olimpiyatlara katılmanın önemini vurgulamak ve olimpiyatlar hakkında genel bilgi verecek yayınlar ve reklam yapılması üzerinde durulmuştur. ${ }^{37}$ Böylece olimpiyatlara katılımın önemi konusunda bir kamuoyu oluşturulmaya çalışılmıştır. Türkiye İdman Cemiyetleri İttifakı tarafindan olimpiyat bütçesinden ayrılan ödenek ile olimpiyatlar hakkında bir kitapçık, futbol kuralları ve yönetmeliği hakkında iki dergi ile yüzme, güreş ve atletizmle ilgili çeşitli yayınlar yapılmıştır. ${ }^{38}$

\section{Olimpiyat Hazırlıkları ve Paris’e Gidecek Sporcuların Seçimi}

Hükümet, olimpiyat hazırlıklarını yakından takip etmiş, gelişmeler hakkında Başbakan İsmet Paşa Türkiye Milli Olimpiyat Komitesi Başkanı Selim Sırn Bey tarafından bilgilendirilmiştir. Selim Sırrı Bey Başbakanlığa gönderdiği 16 Şubat 1924 tarihli yazısında Türk sporcularının büyük bir azim ve inançla çalışıp olimpiyata hazırlandıklarını bildirirken Fransızca olan olimpiyat takvimini de göndermiştir. Ayrıca olimpiyata katılımın önemini ise şöyle ifade etmiştir: "39 “...zat-ı alileri gibi muhterem bir kumandan herkesten iyi taktir eder ki mücadelede kazanmak kadar iyi döğ̈̈şmek de tebcile layık bir harekettir. Binaenaleyh gençlerimiz bu cihan müsabakalarında kazanamasa bile mücadeleden yllmadıklarını herkese göstereceklerdir."

\footnotetext{
${ }^{36}$ Ali Seyfi, “Olimpiyatlara Niçin Gidiyoruz?”, Vakit, 9 Şubat 1924, s.4.

${ }^{37}$ Burhaneddin, "Olimpiyat İşlerimiz", Spor Alemi, (Tarih Belirtilmemiş), No:12, s.3.

${ }^{38}$ BCA: 30..30.0.0/144.34..12/14812.

${ }^{39}$ BCA, 30..10.0.0/144.34..3/1483.
} 
Türkiye, olimpiyat hazırlıklarında esas olarak atletizm, güreş ve futbol dallarında çalışmalara ağılık vermiştir. Türkiye İdman Cemiyetleri İttifakı tarafindan futbol, güreş ve atletizm alanlarına yurt dışından üç yabancı antrenör getirilmesi için arayışa geçilmiştir. Olimpiyatlara yaklaşı üç ay gibi kısa bir süre kala antrenör bulunması işi kolay olmamıştır. Dönemin basını da antrenör arayışı ile ilgili gelişmeleri düzenli olarak kamuoyuna duyurmuşlardır. Yapışan görüşmeler sonucunda altı aylık sözleşme ile İskoç asıllı Billy Hunter aylık otuz İngiliz sterlini karşıllı̆ında futbol takımının antrenörlüğü, Macar Raul Peter aylık yüz dolara güreş antrenörlüğü, Amerika'nın en iyi antrenörlerinden biri olan Tobin ile de yine aylığı yüz dolara atletizm antrenörlüğü için anlaşılmıştır. Antrenörler hemen Türkiye'ye gelerek olimpiyatlara iyi ay kala Mart ayı içinde görevlerine başlamışlardır. ${ }^{40}$

Spor kulüpleri olimpiyatlara katılma kararının kesinleşmesi üzerine çalışmalarına yoğunluk vermişlerdir. Olimpiyatlara katılacak sporcuları kimin seçeceği ise merak ve tartışma konusu olmuştur. Türkiye İdman Cemiyetleri İttifakı'nca olimpiyatlara gidecek sporcuları seçmek üzere Eskişehir'de 20-21 Mart 1924 tarihinde müsabakalar yapılması kararlaştırılmıştır. ${ }^{41}$ Türkiye İdman Cemiyetleri İttifakı Reisi Ali Sami Bey Maarif Vekili Vasıf Bey'i de Eskişehir'e davet ederek Hükümetle sporcular arasında ilişkileri güçlendirmeye çalışmıştır. ${ }^{42}$ Eskişehir'de seçmeler için bir spor sahası yapılmış, sporcular için Eskişehir Hastanesi'nde 180 kişilik bir yatakhane hazırlanmıştır. Ayrıca Eskişehir'de bulunmayan kale, ağ, top, gülle cirit gibi gereken spor malzemeleri de İstanbul'dan temin edilmiştir. ${ }^{43}$ Sporcuların İstanbul ve Anadolu'nun çeşitli şehirlerinden Eskişehir'e ücret ödemeden ulaşmaları için girişimde bulunulmuşsa da bunun kanunen imkânsızlığı karşısında ancak indirimli bilet teminine gidilmiştir. ${ }^{44}$ Hükümet Eskişehir' de yapılacak müsabakaları yakından izlemiştir. Hatta sporcuların İstanbul'dan Eskişehir'e naklinde yaşanan bilet sorunu ile İsmet Paşa bizzat ilgilenmiştir. Marşandiz trenine eklenecek ikinci sınıf bir vagon ile ücretlerde indirim yapılarak sporcuların Eskişehir'e ulaşımı sağlanmıştır. ${ }^{45}$ İstanbul'un dişında Ankara, Adana İzmir gibi Anadolu şehirlerinden Eskişehir'e gelen sporcular arasından seçmeler 20 Mart 1924'te yapılmaya başlanmıştır. ${ }^{46}$ Dönemin gazeteleri muhabir ve fotoğrafçı göndererek

${ }^{40}$ BCA, 30..18.1.1/8.46..5/148-1., Vakit, 3 Mayis 1924, s.4.

${ }^{41}$ Vakit, 19 Mart 1924, s.2.

${ }^{42}$ BCA, 30..10.0.0/144.34..12/14812.

${ }^{43}$ Akşam, 19 Mart 1924, s.1.

${ }^{44}$ BCA, 30..10.0.0/ 144.34..4/ 1484 .

${ }^{45}$ BCA, 30..10.0.0/144.34..4/1484., Vakit, 19 Mart 1924, s.2., Akşam, 19 Mart 1924, s.1.

${ }^{46}$ Vakit, 20 Mart 1924, s.1. 
Eskişehir'de yapılan seçme müsabakalarını takip etmişler ve buna dair haberlere ilk sayfalarında geniş yer vermişlerdir. ${ }^{47}$

Yapılan seçmeler sonucunda sporcular Eskişehir'den İstanbul'a gelerek burada olimpiyat kampına alınmış ve çalışmalarını sürdürmüşlerdir. Olimpiyat bütçesinden ayrılan ödenekle kısmen metruk halde bulunan Kadıköy İttihat Spor Kulübü yeniden düzenlenerek burada bir olimpiyat köyü oluşturulmuştur. Çok sayıda işçi çalıştırılarak futbol sahası antrenmana uygun hale getirilip önce futbolcular kampa alınmıştır. 6 Nisan'dan 8 Mayıs'a kadar süren futbol kampına 30 sporcu katılmış bunlardan 25'i yatılı olarak kalmıştır. Doktor denetiminde sporculara öğle ve akşam yemekleri ile sabah ve ikindi kahvaltısı verilmiştir. Futbolcuların Paris'e gitmek için yola çıkmalarından sonra Kadıköy İttihat Spor Kulübü atlet ve güreşçilere tahsis edilmiş ve burada geçici bir güreş salonu yapılmıştır. Eskişehir'de yapılan seçmelerle belirlenen ve Trabzon'dan İstanbul'a özel davetle gelen Süleyman Rıza Bey gibi 42 sporcu kampa girmiştir. Sporcular kampta sıkı bir antrenmana tabi tutulmuştur. En başarılı olanlar arasından yapılan seçimle olimpiyata katılacak sporcular belirlenmiştir. ${ }^{48}$

Olimpiyat hazırlıkları sürerken gazete köşelerinde olimpiyatlar için ayrılan ödeneğin iyi değerlendirilmesi yönünde tavsiyeler sıklıkla yer almıştır. Hükümet de harcamalarla ilgili yetkililerce bilgilendirilmiştir. Türkiye Milli Olimpiyat Komitesi Başkanı Selim Sırn Bey olimpiyat bütçesini gösteren 22 Mayıs 1924 tarihli bir rapor hazırlayarak Başbakanlığa sunmuştur. Bu raporda 10 Şubat 1924'ten 20 Mayıs 1924'e kadar yapılan ve bu tarihten sonra yapılacak harcamalar tek tek gösterilmiştir. Olimpiyat bütçesi temelde şu kalemlerden oluşturulmuştur: Antrenör, basın-yayın, araç-gereç, sağlık hizmetleri, kamp, sporcular için kıyafet, yol parası, Paris'te ikamet ve iaşe.

Olimpiyata katılacak sporcuların bazıları öğrenci, asker ve memur olduğundan bu sporcular için gereken izinlerin alınması işini de Başbakanlık yürütmüştür. Galatasaray Mektebi, Ticaret Mektebi, Diş̧̧i Mektebi, Mülkiye Mektebi, Mekteb-i Bahriye gibi okullarda öğrenci olan sporcular için Başbakanlık tarafından okullara tek tek yazı gönderilerek Nisan ayından Temmuz sonuna kadar bu öğrencilerin izinli sayılması istenmiştir. ${ }^{49}$ Ayrıca İstanbul Fenerler İdaresi, Şark Şimendiferler İdaresi ve Kadıköy Havagazı

\footnotetext{
${ }^{47}$ Vakit, 22 Mart 1924, s.1., Akşam, 21 Mart 1924, s.1.

48 BCA, 30..10.0.0/144.34..3/1483., Süleyman Rıza Kuğu, Trabzon-Paris 1924 Olimpiyatlarına Yolculuk, Trabzon Araştırmaları Merkezi Yayını, Trabzon, 2012, s.25,39. ${ }^{49}$ BCA, 30..10.0.0/ 144.34..8/1488.
} 
Şirketi'nde çalışan sporcular için de gereken izin alınmıştır. ${ }^{50}$ Ancak bazı memur ve öğrenciler kamp hazırlıklarına katılsa bile Paris'e gitmek için kurumlarından izin alamamıştır. Bunun üzerine Başbakanlık tarafından yeniden yazışmalar başlatılmışsa da bu sporcuların talepleri geri çevrilmiştir. ${ }^{51}$ Örneğin halterde büyük bir yetenek olarak öne çıkan bahriye subayı Üsküdarlı Şevket izin alamamış ve Paris'e gidememiştir. ${ }^{52}$

Futbolcularla birlikte Paris'e gidecek kafilede kimlerin yer alacağı da tartışma konusu olmuştur. Hem Futbol Federasyonu hem de Türkiye İdman Cemiyeti İttifakı yöneticileri gitmek istemiş, özellikle Fransızca bilmeyen yöneticilerin Paris'e gitmek istemesi eleştirilere yol açmıştır. Paris'e ilk giden Uluslararası Olimpiyat Cemiyeti Türkiye temsilcisi Selim Sırrı Bey olmuştur. Lamartin Vapuru ile 24 Nisan'da törenle İstanbul'dan ayrılmıştır. Selim Sırrı Bey'i rıhtımdan arkadaşları ile aralarında Galatasaray Lisesi ve Darülfünun öğrencilerinin de bulunduğu çok sayıda kişi marşlarla uğurlamıştır. ${ }^{53}$

Ekonomik sıkıntılardan dolayı Selim Sırrı Bey için ikinci sınıf bilet alınmış ancak kendisi aradaki farkı ödeyerek birinci sınıf biletle yolculuk yapmıştır. Onca ekonomik güçlüğe rağmen Selim Sırrı Bey'in birinci sınıf biletle Paris'e gitmesi tartışma konusu olunca kendisini şöyle savunmak zorunda kalmıştır. ${ }^{54}$ “...hükümet beni beş kongreye murahhas gönderdi. Bir kere de 1912 olimpiyatlarına yolladı. Daima birinci siniftan yol parası hesap etti ve yevmiye bana beş altın lira verdi. Gençler idare olsun diye bana ikinci kamara bileti aldılar. Düşündüm, vapurumuz Pire'ye uğrayacak ya tesadüfen oradan Yunan murahhası binerse ve tabii birincide seyahat edecek, memleketimin namusu haysiyetini her şeyden ikdam bildiğim için kendi kesemden kurk bir lira ilave ederek biletimi birinciye tahvil ettim."

Paris'e gitmek üzere ilk kafile 8 Mayıs 1924 tarihinde büyük bir kalabalık tarafindan törenle uğurlanarak deniz yolu ile İstanbul'dan yola çıkmıştır. İlk kafileyi Türk futbol milli takımı sporcuları oluşturmuştur. ${ }^{55}$ Kadıköy İttihat Kulübü'nde hazırlanan futbol takımında şu isimler yer

\footnotetext{
${ }^{50} \mathrm{BCA}, 30 . .10 .0 .0 / 144.34 . .7 / 1487$.

${ }^{51}$ BCA,30..10.0.0/144.34..10/14810.

52 Cem Atabeyoğlu, "Halter", Cumhuriyet Dönemi Türkiye Ansiklopedisi, C.8, İletişim Yayınlar1, s.2287.

${ }^{53}$ Akşam, 25 Nisan 1924, s.3.

${ }^{54}$ Selim Sırrı, "Paris Tenzihinin İç Yüzü”, Cumhuriyet, 12 Mayıs 1924, s.4.

${ }^{55}$ Türk futbol takımının ilk rakibi olarak Çekoslovakya gibi güçlü bir takımının çıkması morallerin bozulmasına yol açmıştır. Ancak Almanya'da Karlsruhe Kulübü'nde futbol oynayan Bekir Refet Bey’in Türk Futbol takımı ile olimpiyata katılmak isteği spor çevrelerini umutlandırmış ve sevinçle karşılanmıştır. Bkz: Akşam, 2 Mayıs 1924, s.1.
} 
almıştır: Nedim (kaleci), Hamid, Ali, Cafer, Nihad, İsmet, Kadri, İbrahim, Alaaddin, Zeki, Bekir Refet (Almanya'dan Paris'e giderek milli takıma katılacaktır), Bedri, Mahmet, Sabih, Kemal, Kamil, Kemal ve İzmirli Hamid Bey. 18 futbolcudan oluşan bu ilk kafileye Antrenör Billy Hunter ve Futbol Federasyonu Başkanı Yusuf Ziya (Öniş) Bey'in de refakat etmesi uygun bulunmuştur. Ayrıca futbol takımının yönetimine Türkiye İdman Cemiyetleri İttifakını temsilen Burhaneddin (Felek) Bey ve muhasebe işleri için de Nuri Bey seçilerek Paris'e ilk kafile ile gitmişlerdir. ${ }^{56}$

İlk kafile on günlük uzun bir yolculuktan sonra 18 Mayıs 1924'te Marsilya üzerinden Paris'e ulaşmıştır. Fransız olimpiyat komitesi adına Türk heyetinin refakatine o dönemde Türk dostu olarak tanınan La Kruva tayin edilmiştir. Sporcular olimpiyatların yapılacağı stadyumun hemen yakınına kurulan Colomb olimpiyat köyüne yerleştirilmişlerdir. Fransızlar 1900 Paris Olimpiyatları'nda misafirlerini iyi ağırlayamadıkları düşüncesi ile bu sefer barınmaya önem vermişler, müsabakaların yapılacağı alana yakın bir yerde olimpiyat köyü inşa etmişlerdir. Ayrıca altmış bin seyirci kapasitesi olan "Stad de Colomb" yapılmıştır. ${ }^{57}$ Uluslararası Olimpiyat Komitesi Başkanı Pierre de Coubertin ve Fransız Olimpiyat Comitesi heyeti Başkanı Klary tarafından Türk heyeti kabul edilerek olimpiyatlara hoş geldiniz töreni yapılmıştır. $^{58}$

Futbolcular ilk kafile olarak Paris'e giderken atletler ve güreşçiler Kadıköy'de kampa alınarak hazırlıklarını sürdürmüşlerdir. Olimpiyatlara katılacak bisikletçiler de zemini bu yarışlar için çok uygun olmasa da eski bisikletlerle Taksim Stadyumu'nda yoğun bir şekilde çalışmışlar ve Paris'e gidecekleri günü beklemişlerdir. ${ }^{59} \mathrm{Bu}$ süreçte yaklaşık bir ay sporcular geceli gündüzlü çalışarak müsabaka ve direnç yeteneklerini artırıp takım ruhu kazanmışlardır. ${ }^{60}$

Türkiye İdman Cemiyetleri İttifakı Başkanı Ali Sami Bey'in nezaretinde 23 sporcu, antrenör ve idarecilerden oluşan ikinci kafile 27 Haziran'da İstanbul'dan trenle ayrılmıştır. Ekonomik sıkıntılardan dolayı yataklı vagon alınamamış üçüncü mevki bir trenle giden sporcular ancak nöbetleşerek ya da oturdukları kanepeleri birleştirerek uyuyarak yorucu bir yolculuk yapmıştır. 5 Temmuz'da başlayacak olan uluslararası olimpiyat oyunlarına katılacak ikinci kafile 1 Temmuz'da Paris'e ulaşmıştır. ${ }^{61}$

\footnotetext{
${ }^{56}$ Cumhuriyet, 7 May1s 1924, s.1,6.

${ }^{57}$ Selim Sirr1, a.g.e., s. 17.

${ }^{58}$ Yusuf Ziya, "Türk Sporculuğunda Tarihi Gün”, Vakit, 25 May1s 1924, s.1.

${ }^{59}$ Cumhuriyet, 4 Haziran 1924, s.3.

${ }^{60}$ Cumhuriyet, 16 Mayis 1924, s.5.

${ }^{61}$ Kuğu, a.g.e., s.91., Vakit, 27 Haziran 1924, s.1-2.
} 
Pasaportlarının düzenlenmesinin gecikmesi üzerine bisikletçiler ancak 11 Temmuz'da İstanbul'dan hareket edebilmişlerdir. ${ }^{62}$

Ayrıca olimpiyatları izlemek için Maarif Vekâleti'nce liselerden beden eğitimi öğretmenleri seçilerek Paris'e gönderilmiştir. Ankara Lisesi'nden Mehmet Bey, İzmir Lisesi'nden Nuri Bey ve Adana Lisesi'nden Sıdkı Bey, Paris'te olimpiyat müsabakalarını takip etmek ve beden eğitimi hakkında incelemelerde bulunmak üzere 14 Haziran 1924'te Paris'e hareket etmişlerdir. ${ }^{63}$

\section{Paris Olimpiyatlarında Türk Milli Takımı}

1924 Paris Olimpiyatları 4 Mayıs 1924 tarihinde futbol müsabakalarıyla başlamıştır. Yirmi bin seyirci önünde oynanan ilk maç Fransa ile Romanya takımları arasında yapılmış ve Fransa'nın galibiyetiyle sonuçlanmıştır. ${ }^{64}$ Futbol müsabakalarının ardından olimpiyatların resmi açılış töreni 5 Temmuz'da Paris'te Colomb Stadyumu'nda yapılmıştır. Olimpiyatlara katılan altı bin sporcu otuz bin seyirci önünde resmigeçit yapmışlardır. $\mathrm{Bu}$ törene katılan Türk sporcuları ilk defa dünyanın en büyük ve en prestijli spor organizasyonunda Türk bayrağını diğer milletlerle yan yana taşımışlardır. ${ }^{65}$

Türkiye, 44 ülkeden 135'i kadın 2954'ü erkek olmak üzere 3089 sporcunun katıldığı olimpiyatlarda 40 erkek sporcu ile yer almıştır. Spor dallarına göre olimpiyatlarda Türk milli takımının durumu şu şekildedir:

Futbol: Olimpiyatlarda Türk futbol takımı şansız bir eşleşme ile ilk maçını dünyanın en iyi takımlarından biri olarak gösterilen Çekoslovakya ile yapmıştır. Türk Futbol Milli takımı Billy Hunter'ın antrenörlüğünde 25 Mayıs'ta Çekoslovakya'ya 5-2 mağlup olmuştur. Maçta Türk Milli Takımı şu kadro ile oynamıştır: Kalede Nedim, Ali, Cafer, Kadri, İsmet, Nihat, Bedri, Bekir Refet, Zeki, Alâeddin, Mehmet. Yağmurlu bir günde kaygan sahada yapılan maçta Türkiye'nin gollerini Almanya'dan gelerek milli takıma katılan Bekir Refet atmıssa da dünyanın en kuvvetli takımlarından biri olarak görülen Çek takımı karşısında Türk futbol takımı olimpiyata veda etmiştir. ${ }^{66}$ Türkiye'nin ilk maçta İspanya, Bulgaristan, Litvanya Polonya gibi takımlar yerine çok güçlü bir takım olarak görülen Çekoslovakya ile karşılaşması büyük bir talihsizlik olarak görülmüştür. 24 ülkenin katıldığ 1

\footnotetext{
${ }^{62}$ Vakit, 12 Temmuz 1924, s.1.

${ }^{63}$ Cumhuriyet, 14 Haziran 1924, s.5.

${ }^{64}$ Cumhuriyet, 7 May1s 1924, s.6.

${ }^{65}$ Vakit, 7 Temmuz 1924, s.1.

${ }^{66}$ Cumhuriyet, 26 Mayıs 1924,s.1., Akşam, 27 Mayıs 1924, s.3.
} 
futbol turnuvasında dünya şampiyonluğunu kazanan Uruguay takımı olmuştur. $^{67}$

1924 Paris Olimpiyatları'nda Türk futbolcuları dünyanın en seçkin takımlarını ve futbolcularını izleyerek görgü ve tecrübelerini artırma firsatı bulmuşlardır. Olimpiyat sonrasında Spor Alemi Dergisi'nin sporcularla görüşerek sorduğu "Olimpiyat müsabakalarından istifade ettiniz mi?" sorusuna futbolcular olumlu yönde cevaplar vererek olimpiyatlara katılmanın önemine değinmişlerdir. Kaleci Hamid Bey; "Olimpiyat müsabakalarında dünyanın en kuvvetli takımları karşılaşıyor. Bunları görüp de istifade etmemek kabil midir? Olimpiyat müsabakalarindan istifade ettiğimizi turnede icra ettiğimiz maçlarda ihraz ettiğimiz galibiyetlerle ispat ettik. Uruguay'la Çekoslovakya'nın iyi oyunlarını gördük. Dünyanın en kuvvetli muhacimleri Uruguay'da en iyi müdafaası da Çekoslovakya'dadır." Alâeddin Bey ise: "Olimpiyat müsabakalarından büyük istifadeler tesis etmiş olduğumuza kailim. Evvela her milletin kuvvet yolundaki derece-i kabiliyetlerini ölçmek firsatına nail oldum. Saniyen isimlerini işittiğimiz dünya futbolcularının oyunlarını görerek futbolun bugünkü yüksek inceliğini takdir ettim. Zannediyorum ki Türk, futbolunu bu günden itibaren daha bilerek oynayacaktır." sözleriyle olimpiyatın futbol için yararını anlatmışlardır. ${ }^{68}$

Türk Milli Futbol Takımı olimpiyat dönüşünde Türk futbol tarihinde "Şimal Turnuvası" adıyla geçen ve İskandinavya ülkelerine kadar uzanan bir geziye çıkmış ve burada elde ettiği parlak galibiyetlerle dikkatleri çekerek olimpiyatlarda yaşattığı üzüntüyü telafi ettirebilmiştir. Helsinki'de Finlandiya'yı 4-2, Talin'de Estonya'y1 4-1, Riga'da Litvanya'y1 3-1 yenen Türk Milli Takımı ayrıca temsili mahiyette oynadığ 1 maçları da kazanmıştır. ${ }^{69}$ Gazeteler bu müsabakalara yer vererek, aynı dönemde Paris'ten atlet ve güreşçilerden gelen haberler yüz güldürücü olmadığından, Türk Milli Takımı'nın elde ettiği galibiyetlere geniş yer vermişlerdir. ${ }^{70}$

Gazetelerde arka arkaya gelen başarıların Türkiye'nin tanıtımına olan katkısı vurgulanarak 1924 Paris olimpiyatlarında futbolda yaşanan şanssızlık şu şekilde belirtilmiştir:" "Türklerin nargilelerini bırakıp da zeka ile kuvveti

\footnotetext{
${ }^{67}$ Vakit, 26 May1s 1924, s.1., Cumhuriyet, 24 Haziran 1924, s.5.

${ }^{68}$ Spor Alemi, (Tarih Belirtilmemiș), No:25, s.54-55.

${ }^{69}$ Cem Atabeyoğlu, "Futbol", Cumhuriyet Dönemi Türkiye Ansiklopedisi, C.8, İletişim Yayınlar1, s.2200.

${ }^{70}$ Yusuf Ziya, "Milli Takımımızın Dördüncü Zaferi”, Vakit, 30 Haziran 1924, s.1,3., Yusuf Ziya, "Vatana Doğru”, Vakit, 5 Temmuz 1924, s.1,3., Cumhuriyet, 20 Haziran 1924, s.1., Akşam, 25 Haziran 1924, s.1.

${ }^{71}$ Cumhuriyet, 24 Haziran 1924, s.3.
} 
aynı zamanda faaliyete mecbur eden meşin topun arkasında koşmaya başlar başlamaz derhal gösterdikleri bu muvaffakiyet öteden beri mazlum olduğu kadar mazlum kalan memleketimiz için en şerefli bir propaganda oldu. Hele talih bir az insafsızlık etmeyip de bugün galip geldiğimiz milletlerden birini mesela Íspanya, Litvanya, Polonya, Bulgaristan, Romanya, Leh futbolcularını Paris'te de karşımıza çıkarmış olsa idi olimpiyatlarda bu kadar çabuk elimine olmayacak ve orada da başka bir şeref kazanacaktık."

Güreş: Modern güreş (alafranga güreş) "minder güreşi” adiyla 1910'larda Türkiye'ye gelmiş ancak yetenekli Türk sporcular kendi kendilerini yetiştirmekle yetinmek zorunda kalmışlar ve modern güreşin inceliklerini öğrenememişlerdir. Buna rağmen alaturka güreşten kalma bilgileriyle modern güreşte büyük varlık göstermişlerdir. Türk güreşçilerinin de Paris Olimpiyatları'na katılması gündeme gelince güreşçilere modern teknikleri öğretecek bir antrenöre ihtiyaç duyulmuştur. Macaristan'dan getirilen Raul Peter olimpiyatlara hazırladığı Türk güreşçilerine modern güreşin inceliklerini tanıtmış ve öğretmiştir. ${ }^{72}$

Kadıköy'deki hazırlık kampına katılan güreşçilerden ancak Cenap, Üsküdarlı Fuat, Dürrü, Mazhar ve Tayyar'dan oluşan bir ekip Paris'e gitmiş̧ir. Nazmi ve Kadri Beyler hazırlık çalışmalarını tamamlayamadan kamptan ayrılmaları, Sadullah Bey atletlerin çalışması sırasında savrulan ciritin göğsüne saplanması sonucunda sakatlanması ve Vehbi Bey de işinden izin alamadığından dolayı güreş kafilesine girememişlerdir. ${ }^{73}$

Paris'te 7 Temmuz'da başlayan güreş müsabakalarına ilk olarak Türk güreşçilerden ikisi katılmış ve sonuçta yenilmişlerdir. Hafif sıklette Fuad Bey 3 dakika 52 saniyede Finlandiyalı rakibine mağlup olurken yarı ağır sıklette Seyfi Bey'in İsveçli rakibi 5 dakikalık mücadeleden sonra galip gelmiştir. Müsabakaların ikinci gününde Avusturyalı rakibi, Mazhar Bey'i sayı hesabıyla mağlup ederken Harbiye Mektebi öğrencisi olan Tayyar Bey ilk maçında İspanyol rakibine 3 dakika 45 saniyede galip gelmiştir. Bu, Türk sporcuların Paris'te elde ettiği ilk başarı olmuştur. ${ }^{74}$ İkinci maçını yaptı̆̆ Fransız güreşçi 11 dakika dirense de bu oyunu da Tayyar Bey kazanmıştır. Ancak üçüncü maçında Finli güreşçi karşısında kolundan sakatlanmış ve puan hesabıyla mağlup olmuştur. Üç gün üst üste maç yapan Tayyar Bey bir maç hakkı daha olmasına rağmen kolu sakatlandığı ve dizleri yarıldığından doktorlar güreşmesine izin vermeyince yarışmadan çekilmiştir. Tayyar

\footnotetext{
${ }^{72}$ Cem Atabeyoğlu, “Güreş”, Cumhuriyet Dönemi Türkiye Ansiklopedisi, C.8, İletişim Yayınları, s.2219.

${ }_{73}$ Cumhuriyet, 27 Haziran 1924, s.1., Cem Atabeyoğlu, a.g.m., s.2219.

${ }^{74}$ Cumhuriyet, 13 Temmuz 1924, s.6.
} 
Bey'in sakatlanması olimpiyatta elde edilecek ilk şampiyonluk adına Türk güreşi için büyük bir şanssızlık olmuştur. ${ }^{75}$

1924 Paris Olimpiyatları Türk güreşçileri için büyük bir görgü ve tecrübe vesilesi olmuştur. Olimpiyat sonrasında Spor Alemi Dergisi'nin "Olimpiyat müsabakalarından istifade etiniz mi? sorusuna güreşçi Fuad Bey "kendi kendime pek çok istifade ettim" derken yönetim ve seyahatle ilgili şikayetlerini ise şöyle dile getirmiştir: " "Seyahate gece ve gündüz oturarak gittik. Tasarrufa riayet edelim derken kabiliyet ve isti'datımizdan düşürüldük. Paris'te bir idmancı için en ehemmiyet verilecek şey olan gıdayı ihmal ediyorduk ki Türk mutfağında bir Rumun pişirdiği yemekten başka her şeyi yiyorduk. O yemekhanenin pisliğini tasvir etmek için bir iki gazete sütunu kafi gelmez. Mesela bana zayıflamak lazım gelirken makarna veriliyordu. Zayıflamamaları lazım gelenlere iki üç tane kuşbaşı et veriliyordu."

Atletizm: Rauf, Şekip, Unvan, Mazhar, Ömer Besim, Lütfi, Said, Neşet, Hüseyin, Ekrem ve Süleyman Beyler atletizm alanında Türkiye'yi temsil etmek üzere Paris'e gitmişlerdir. Yüz metre sürat ve 4X100 metre bayrak yarışlarına katılan Rauf ve Şekip ilk turda elenerek başarı gösterememişlerdir. Ömer Besim Bey 800 ve 1500 metre yarışlarına katılmış ve ilk turdaki seçmelerde elenmiştir. Hüseyin ve Said Beyler de 4X100 metre bayrak yarışında ilk turda elenmiştir. Unvan, Ekrem, Mazhar, Lütfi, Neşet ve Süleyman Beyler ise isimlerinin zamanında yarışacakları dallar için bildirilmemesi gibi yönetimden kaynaklanan koordinasyonsuzluk ve acemiliğin de etkisiyle yarışmalara katılamamıştır. ${ }^{77}$ Diğer branşlara göre atletizmde başarı umudu yüksek olduğundan atletizm müsabakaları Türkiye için hayal kırıklığıyla sonuçlanmıştır. ${ }^{78}$

Türk sporcularını hazırlamak üzere Türkiye İdman Cemiyetleri İttifakı tarafindan Avrupa'dan atletizm antrenörü de getirilerek sporcuların çağdaş yöntemler çerçevesinde olimpiyatlara hazırlanması düşünülmüştür. $\mathrm{Bu}$ amaçla getirilen Amerikalı Tobin sistemli ve bilinçli çalışmaları kısa sürede sonuç vermiş, bunun sonucu olarak aralarında Ömer Besim (Koşalay) Bey'in de bulunduğu genç yetenekler ortaya çıkmıştır. Ömer Besim Bey Paris olimpiyatı ile başlayan ve 13 yıl sürecek başarılı atletizm hayatında 6 ayrı mesafede 29 Türkiye rekoru kırmıştır. Paris’te gördüğü modern çalışmaları

\footnotetext{
75 Spor Alemi, (Tarih belirtilmemiş), Numara: 25, s.61., Türkiye Milli Olimpiyat Komitesi'nin 100. Yıl1, (Der:Altuğ İstanbulluoğlu), TMOK Yayını, İstanbul, 2008, s.182.

${ }^{76}$ Spor Alemi, (Tarih Belirtilmemiş), No:25, s.55.

${ }^{77}$ Türkiye Milli Olimpiyat Komitesi'nin 100. Y111, s.181., Cumhuriyet, 27 Haziran 1924, s.1.

${ }^{78}$ Cumhuriyet, 13 Şubat 1924, s.3.
} 
Türkiye'de ilk uygulayan atlet olan Ömer Besim yine Paris Olimpiyatları'nda Amerikalı atletlerin üzerinde gördüğü eşofmanın büyük yararını anlayıp Amerika'dan getirttiği eşofmanı Türk atletizminde ilk giyen atlet de olmuştur. $^{79}$

Halter (Gülle Kaldırma):Türkiye'nin ilk haltercileri jimnastikçiler olmuş ve 1920'li yılların başlarında ortaya çıkan Gülleci Cemal ve Neyzen Şevki adında iki hevesli genç bu sporda büyük üstünlük göstermişlerdir. Genç halterciler Türkiye'yi uluslararası alanda temsil eden ilk Türk halterciler olmuştur. Olimpiyatlara katılan bu iki halterciden Gülleci Cemal tüy siklette, kolundaki sakatlığa rağmen toplam 345 kilo ile otuz dokuz rakip arasında on ikinci olmuştur. Hazırlık kamp çalışmaları sırasında orta sıklette büyük bir yetenek olarak kendini göstermiş olan Üsküdarlı Şevket çalışmalar sırasında 125 kilo silkme yapmasına rağmen Bahriye subayı olduğu için izin alamadığı için Paris'e gidememiştir. 1924 Paris olimpiyatlarında yarı ağır sıklette altın madalya kazanan Kadin'in 124 kilo ile şampiyonluğu kazanması oldukça ilginçtir. Böylece Türkiye halterden gelecek bir altın madalyadan da mahrum kalmıştır. ${ }^{80}$

Eskrim: Eskrim Federasyonu Türkiye İdman Cemiyetleri İttifakı çatısı altında 1923 yılında oluşturulmuştur. Türkiye'yi eskrim dalında 1924 Paris Olimpiyatları'nda Fuat (Balkan) Bey temsil etmiştir. Kılıç dalında yarışmış ancak dereceye girememiştir. ${ }^{81}$

Bisiklet:1924 Paris Olimpiyatları'nda Türkiye Bisiklet Federasyonu Başkanı hem de Türkiye Olimpiyat Cemiyeti üyelerinden Muvaffak (Menemencioğlu) Bey'in çabasıla Türkiye'nin de temsil edilmesi söz konusu olmuştur. Taksim Stadyumunda hazırlanan bisikletçilerden İzmir Altay Kulübü'nden Raif İzzet Bey, Beşiktaş Kulübü'nden Cambaz Fahri ve Nişantaşı'ndan Cavit Bey'ler seçilerek Paris'e götürülmüşlerdir. Ancak orada özel yarışma bisikletleri sağlanamadığından yarışlara katılamamışlardır. Fakat bu üç Türk bisikletçi Türkiye'ye yeni bir görüş ve anlayış içinde dönmüşlerdir. ${ }^{82}$ Türkiye'de bisiklet sporunun temelini atan kişi olarak tanınan Muvaffak Bey'ce Türk bisikletçilerine Paris'te bir bisiklet fabrikasında staj imkanı bulunmuş ve bu sporcuların bisiklet mekanizmasını daha yakından tanımaları sağlanmıştır. Böylece Paris Olimpiyatları

\footnotetext{
${ }^{79}$ Cem Atabeyoğlu, "Atletizm”, Cumhuriyet Dönemi Türkiye Ansiklopedisi, C.8, İletişim Yayınları, s.2263.

${ }^{80}$ Cem Atabeyoğlu, "Halter”, Cumhuriyet Dönemi Türkiye Ansiklopedisi, C.8, İletişim Yayınları, s.2287.

${ }^{81}$ Cem Atabeyoğlu, "Eskrim”, Cumhuriyet Dönemi Türkiye Ansiklopedisi, C.9, İletişim Yayınları, s.2309.

${ }^{82}$ Spor Alemi, (Tarih Belirtilmemiş), Numara:25, s.19.
} 
sonrasında bisiklet sporu yeni görüş ve anlayışla Türkiye'de gelişme göstermeye başlamıştır. ${ }^{83}$

\section{Türk Basınında 1924 Paris Olimpiyatları}

1924 Paris Olimpiyatları Türk spor tarihinde bir dönüm noktası olduğu gibi Türk basın tarihi açısından da büyük önem taşımaktadır. Gazeteler savaşlardan, siyasal krizlerden ve ekonomik güçlüklerden bunalmış okuyucularına adeta bir şenlik havasında Paris'te yaşanan gelişmeleri haber vermişlerdir. Olimpiyatlara futbol, güreş, atletizm, halter, eskrim ve bisiklet alanlarında sporcu katılmasına karşın ağırlıklı olarak futbol takımıyla ilgili haberler basında yer almıştır. Bunda diğer sporlara göre Türkiye'de futbolun daha popüler olması ve futbol takımının diğer alanlara göre daha iyi olduğu düşüncesi etkili olmuştur.

Olimpiyatlar Türkiye Cumhuriyeti’nin resmi olarak katıldığı ilk büyük spor organizasyonu olduğundan bazı gazeteler oyunları takip etmek üzere Paris'e muhabir göndermiş, bazıları da milli takımda yer alan sporcuları ya da yöneticileri yazar olarak değerlendirmiştir. Örneğin Vakit Gazetesi'nin muhabirliğini Türkiye Futbol Federasyonu Başkanı Yusuf Ziya Bey yapmıştır. "Paris Mektupları" adını taşıyan köşesinde olimpiyatlara dair haber ve yorumlara yer vermiştir. Akşam Gazetesi Paris'e hem muhabir göndermiş hem de Zeki, Alaeddin ve Nihat Beyler gibi milli takımın üç sporcusu izlenimlerini bu gazete için bildirmişlerdir. Cumhuriyet Gazetesi ise olimpiyat oyunlarını Uluslararası Olimpiyat Komitesi Türkiye temsilcisi olarak Paris’te bulunan Selim Sırrı Bey aracılığıyla takip etmiştir. Selim Sırrı Bey olimpiyat haberlerini vermekle yetinmemiş aynı zamanda Paris'in spor okullarını ve Fransa'nın spordaki gelişmişliği üzerinde de durmuştur. ${ }^{84}$

Dönemin gazetelerinde sadece Paris'ten gelen spor haberleri yer almamış, muhabirler Paris'e dair genel izlenimlerini de haber yapmışlardır. Mustafa Kemal Paşa'nın da bulunduğu balmumu müzesinden Paris'in gece eğlencelerine pek çok konuda haberlere yer verilmiştir. ${ }^{85}$

Sporcuların İstanbul'dan yola çıkış ve Paris'e varışından itibaren yaşanan gelişmeler gazetelerde günü gününe yer bulmuştur. Siyasi ve ekonomik buhranlardan bunalmış Türk kamuoyu spor gibi farklı bir konuda yaşanan gelişmeleri gazetelerden takip etmiştir. Spor haberlerinin yaygın

\footnotetext{
${ }^{83}$ Cem Atabeyoğlu, "Bisiklet”, Cumhuriyet Dönemi Türkiye Ansiklopedisi, C.9, İletişim Yayınlar1, s.2302-2303.

${ }^{84}$ Vakit, 9 Mayis 1924, s.1., Cumhuriyet, 7 May1s 1924, s.6., Cumhuriyet, 29 Haziran 1024, s.5., Akşam, 9 Mayıs 1924, s.1.

${ }^{85}$ Said Tevfik, "Paris Gezilirken-Atletlerimize Intizar", Akşam,25 Haziran 1924, s.3.
} 
olmadığı 1920'li yılların başında gazeteler spor başlığı altında olimpiyatlara birden fazla sütun ayırmışlardır. Olimpiyat haberleri nüfus mübadelesi, Musul sorunu gibi iç ve dış politika ağırlıklı gündemi bir nebze olsa değiştirmiştir. Çoğu zaman iç karartıcı politik haberlerin yanında spor haberleri de gazetelerin ilk sayfalarında yerini almış ve halkın spora ilgisini artırmıştır.

Başarı gösterilemese de olimpiyatlara katılımın önemi gazetelerde sıklıkla vurgulanmıştır. Cumhuriyet Gazetesi'nde yayınlanan "Olimpiyatlara İştirak Etmekle Ne Kazandık?" başlıklı yazıda bu durum şu şekilde ifade edilmiştir. ${ }^{86}$

“...mağlup bile olsak Türklerin öyle zan edildiği gibi şalvar içinde kımıldamaya üşenen insanlar değil, onlar gibi hatta onlara nispetle daha çelimsiz daha naif mahluklar olduğunu, aralarında onlar gibi medeni sporlarla alakadar bir gençlik kitlesi bulunduğunu bütün dünyaya tanıtmış olacak biz de varız diyebilecektik. Bu öyle bir şey idi ki en büyük propagandalar Türk sporcularının temin edebileceği şerefin yanında pek sönük kalacaktı. Biz bu kadarına bile mütevekkil iken ve gider gitmez bizi karşılayan da filhakika bir talihsizlik olmuştu. Karşımıza çıkan Çek’ler dünyanın en müthiş futbolcuları idi."

Olimpiyatlara katılımın dünya sporu hakkında Türk sporcularına bir fikir vermek ve geleceğe dair bir amaç edindirerek bunun için çalışmaya başlamasını sağlamak olduğu sıklıkla basında yer almış ve bu yönde bir kamuoyu oluşturulmaya çalışılmıştır. Başarılı olunamasa da edinilen bilgi ve deneyimlerin gelecek olimpiyatlarda başarı getireceği inancıyla olimpiyat hayalleri bir sonraki olimpiyat olan 1928 Amsterdam Olimpiyatları'na ertelenmiştir.

\section{Sonuc}

Dünyanın en büyük spor organizasyonu olan olimpiyatlara Türkiye Cumhuriyeti resmi olarak ilk defa 1924 yılında Paris'te katılmıştır. Kurtuluş Savaşı sonrasında diplomatik yalnızlıktan kurtulma ve tanınma mücadelesi veren yeni Türk Devleti olimpiyatları iyi bir propaganda arac1 olarak görmüştür. Kıt kaynaklarına rağmen büyük bir özveri gösterip ödenek ayırarak sporcularını Paris'e göndermiştir.

Türk sporcularının 1924 Paris Olimpiyatları'nda resmen yer alması Türk sporu tarihi açısından bir dönüm noktası olmuştur. Sporcular başarı gösteremese de olimpiyat ruhunu yaşamış ve gelecek oyunlar için daha çok

\footnotetext{
${ }^{86}$ Cumhuriyet, 24 Haziran 1924, s.3.
} 
çalışma azmi ile dönmüşlerdir. Sporcular farklı spor dalları ve tekniklerini görerek bilgilerini artırmışlar ve bunları uygulamaya çalışmışlardır. Böylece olimpiyatlara katılım yıllarca savaşların gölgesinde kalmış Türk sporunun gelişmesinde itici güç olmuştur. Dönemin basınında çıkan olimpiyat haberleri de savaşlar, siyasi ve ekonomik buhranlardan bunalmış Türk kamuoyu için farklı bir konu olmuş ve halkın spora ilgisini artırmıştır.

Daha ilk günden itibaren yıllarca süren savaşlardan bitkin düşmüş bir toplumun gençliğinin büyük başarılara hemen imza atamayacağı bilinmesine rağmen Türkiye Cumhuriyeti Hükümeti olimpiyatlara katılımı önemsemiş ve gerekli finansmanı sağlamıştır. Mustafa Kemal Paşa'nın liderliğinde kurulan Modern Türkiye Devleti her alanda olduğu gibi spora verdiği destekle de büyük bir devlet olduğunu göstermiştir.

\author{
Kaynakça \\ Arşiv Belgeleri \\ Başbakanlık Cumhuriyet Arşivi: Fon Kodu/ Yer No/ Dosya No \\ BCA: $30 . .10 .0 .0 / 144.34 . .3 / 1483$ \\ BCA: 30..10.0.0/ 144.34..4/1484 \\ BCA: $30 . .10 .0 .0 / 144.34 . .7 / 1487$ \\ BCA: 30..10.0.0/ 144.34..8/ 1488 \\ BCA: $30 . .10 .0 .0 / 144.34 . .10 / 14810$ \\ BCA: $30 . .30 .0 .0 / 144.34 . .12 / 14812$ \\ BCA: $30 . .18 .1 .1 / 8.46 . .5 / 148-1$ \\ BCA: 30..18.1.1/ 8.47..14/- \\ Resmi Yayınlar \\ TBMM Zabıt Ceridesi: Devre:II, Cilt:7, İçtima Senesi:II, On ikinci İçtima, \\ 15.3.1340. \\ TBMM Zabıt Ceridesi: Devre:II, Cilt:8/1, İçtima Senesi:II, Kırkıncı İçtima, \\ 17.4.1340 \\ Süreli Yayınlar \\ Akşam \\ Cumhuriyet \\ Spor Alemi \\ Vakit \\ Kitap ve Makaleler
}

Ali Naci; "Olimpiyata Behemehâl Gitmeli miyiz, Gitmesek Ne Kaybederiz?", Akşam, 6 Şubat 1924, s.3.

Ali Seyfi; “Olimpiyatlara Niçin Gidiyoruz?”, Vakit, 9 Şubat 1924, s.4. 
Atabeyoğlu, Cem; “Atletizm”, Cumhuriyet Dönemi Türkiye Ansiklopedisi, C.8, İletişim Yayınları, s.2262-2272.

Atabeyoğlu, Cem; "Bisiklet”, Cumhuriyet Dönemi Türkiye Ansiklopedisi, C.9, İletişim Yayınları, s.2301-2304.

Atabeyoğlu, Cem; "Cumhuriyet Döneminde Spor Politikası", Cumhuriyet Dönemi Türkiye Ansiklopedisi, C.8, İletişim Yayınları, 1983, s.2187-2197.

Atabeyoğlu, Cem; "Eskrim", Cumhuriyet Dönemi Türkiye Ansiklopedisi, C.9, İletişim Yayınları, s.2309-2310.

Atabeyoğlu, Cem; "Futbol", Cumhuriyet Dönemi Türkiye Ansiklopedisi, C.8, İletişim Yayınları, s.2198-2218.

Atabeyoğlu, Cem; "Güreş", Cumhuriyet Dönemi Türkiye Ansiklopedisi, C.8, İletişim Yayınları, s.2219-2235.

Atabeyoğlu, Cem; "Halter", Cumhuriyet Dönemi Türkiye Ansiklopedisi, C.8, İletişim Yayınları, s.2286- 2288.

Atabeyoğlu, Cem; Sporda Devlet mi? Devlette Spor mu?, Türkiye Milli Olimpiyat Komitesi Yayınları, İstanbul 2001.

Atabeyoğlu, Cem; "Türkiye Milli Olimpiyat Komitesi", Cumhuriyet Dönemi Türkiye Ansiklopedisi, C.8, İletişim Yayınları, 1983, s.2190-2191.

Burhaneddin; "1924 Olimpiyadı Ne Olacak...", Spor Alemi, 22 Teşrin-i sani 1340, No:5, s.3-4.

Burhaneddin; "Hükümetin Spora Karşı Şayan-ı Şükran Alakası", Spor Alemi, 13 Kanun-1 sani 1924, No:8-9, s.3-4.

Burhaneddin; “Olimpiyat İşlerimiz”, Spor Alemi, (Tarih Belirtilmemiş), No:12, s.23.

Eşref Şefik; “1924 Olimpiyatına İştirakin Mahzurları”, Akşam 12 Şubat 1924, s.3.

Fişek, Kurthan; Türkiye Spor Tarihi, Gerçek Yayınevi, İstanbul, 1985.

Olimpiyat Oyunlarının 100.Yılında Türkiye, (Der: Cüneyt E. Koryürek) Türkiye Milli Olimpiyat Komitesi Yayını, İstanbul, 1997.

Kahraman, Atıf; Osmanlı Devleti'nde Spor, Kültür Bakanlığı Yayınları, Ankara 1995.

Kuğu, Süleyman Rıza; Trabzon-Paris 1924 Olimpiyatlarına Yolculuk, Trabzon Araştırmaları Merkezi Yayını, Trabzon, 2012.

Said Tevfik; "Paris Gezilirken-Atletlerimize İntizar", Akşam, 25 Haziran 1924, s.3.

San, Haluk; Belgeleri ile Türk Spor Tarihinde Olimpizm ve Olimpik Hareket, Hürriyet Ofset Matbaacılık ve Gazetecilik, İstanbul, 1985.

San, Haluk; Türk Sporunda Atatürk, Toplumsal Dönüşüm Yayınları, İstanbul, 2000.

Selim Sırrı; Beynelmilel Olimpiyat Oyunları, Türkiye İdman Cemiyetleri İttifakı Yayını, İstanbul, 1924.

Selim Sırrı; “1924 Olimpiyatları ve Lozan Mukarreratı”, Spor Alemi, 8 Mart 1923, No:23, s.4-5.

Selim Sırrı; "Paris Tenzihinin İç Yüzü”, Cumhuriyet, 12 Mayıs 1924, s.4. 
Türkiye Milli Olimpiyat Komitesi’nin 100. Yıll, (Der: Altuğ İstanbulluoğlu), TMOK Yayını, İstanbul, 2008.

Yusuf Ziya; Olimpiyat Oyunlarına Nasıl Gidiyoruz? Vakit, 29 Şubat 1924, s.3.

Yusuf Ziya; "Türk Sporculuğunda Tarihi Gün”, Vakit, 25 Mayıs 1924, s.1.

Yusuf Ziya; "Milli Takımımızın Dördüncü Zaferi”, Vakit, 30 Haziran 1924, s.1,3.

Yusuf Ziya; "Vatana Doğru”, Vakit, 5 Temmuz 1924, s.1,3. 